\title{
Remembering Don Lindberg: Two Letters
}

\author{
Randolph A. MILLER M.D. ${ }^{1}$ \\ Emeritus Professor, Biomedical Informatics, Vanderbilt University, U.S.A.
}

\begin{abstract}
Keywords. Donald A.B. Lindberg M.D., Randolph A. Miller M.D.; biomedical informatics; leadership, U.S. National Library of Medicine
\end{abstract}

\section{Introduction}

The memoirs below are excerpted from two letters I wrote to Donald A.B. Lindberg M.D. on his retirement in 2015 and Mary Lindberg, Don's wife, after his death in 2019. The letters cover aspects of Don's character, career, and contributions to biomedical informatics. The letters add a tribute to Mary Lindberg, whose support nurtured the careers of many researchers and practitioners in biomedical informatics.

\section{Letter to Don and Mary Lindberg when Dr. Lindberg retired as NLM's director in March 2015}

Dear Don and Mary,

Thank you for serving so graciously as the First Family (like George and Martha) of American biomedical informatics - from the field's infancy to its current maturity. Your examples and initiatives created a community that cares about people and each other. That Mary has shared in and contributed to meetings and activities in our field says much about you and your gifts of leadership and compassion.

A majority of faculty members in U.S. academic biomedical informatics units, including me, owe their careers to the training programs, institutional initiatives, and sponsored research grants that Don initiated during his tenure at the National Library of Medicine (NLM). Building Don's exemplary leadership as its first President, the American Medical Informatics Association (AMIA) grew to become the foremost organization promoting the field. Beginning with Don's formative term as its President, AMIA served as a respected national forum and advocate for informatics policies and priorities.

Don's passion in recent years for telling the story of Native Americans, both in general and concerning health care, exemplifies how he initiates diverse projects with a unique commitment to excellence. In reading Kent Nerburn's book, Neither Wolf Nor Dog, my wife Linda and I at times saw aspects of Don in the way Nerburn objectively and authentically conveys the perspective of Native Americans [1].

At other places in the book, we also perceived Don as Dan, the wise, older Native American philosopher, at all times taking a broader view of the field of biomedical

\footnotetext{
${ }^{1}$ Corresponding author: Randolph A. Miller; E-mail: ramiller49@icloud.com.
} 
informatics - knowing instinctively where it has been, where it is now, and where it should go.

In the book, Dan's words explain why Don has been among the longest-serving directors within the National Institutes of Health in recent times:

'There are leaders, mand there are rulers. We Indians are used to leaders. When our leaders don't lead, we walk away from them. When they lead well, we stay with them.

White people never understand this. Your system makes people rulers by law, even if they are not leaders. ... How can a calendar tell us how long a person is a leader? That's crazy. A leader is a leader as long as the people believe in him and as long as he is the best person to lead us. You can only lead as long as people will follow.

That's why Sitting Bull was a leader. He was needed by the people and the people followed him. He was brave. He was smart. He knew how to fight when he had to. And he understood what the white man [i.e., government] was all about. People saw that he could not be tricked by the white man, so they followed.'

Otherwise, Linda and I deeply treasure the occasions when you devoted the time to get to know our family. When you visited Pittsburgh in the 1980s, Mary prepped our young daughters for the prescient photos that Don took of them, which accurately forecasted their adult visages. Mary spent a wonderful time with Linda's mother that I think each valued highly over the ensuing years. Similarly, it was a profound honor to be entrusted with the care of Mary's aunt in Pittsburgh despite difficult circumstances. One wonders if the Creator dealth with in poetic justice when Mary later delivered compassionate hospice care to Linda's aunt.

We also enjoyed walks with you through the streets of Europe - especially in Zurich and Paris - and memorable dinners in restaurants as part of the Health on the Net (HON) Foundation activities started by our friend, Jean-Raoul Scherrer.

Thank you so much for being who you are. To paraphrase Star Trek's Spock, we hope you will continue to live long and prosper in retirement.

\section{Letter to Mary Lindberg after Dr. Lindberg's death in August 2019}

Dear Mary,

With deep sadness and a profound sense of esteem, Linda and I learned of Don's passing last month. As Yoda of the Star Wars movies said on momentous occasions, "There has been a great disturbance in the Force." We extend our condolences to you and your family.

No individual influenced my career in biomedical informatics as much as Don. Through his pioneering leadership of the National Library of Medicine (NLM) during three decades, the NLM's sponsorship of grants and training programs that influenced hundreds of institutions and thousands of individuals, and Don's leadership of the American Medical Informatics Association (AMIA) during its formative stage, he created a flourishing environment for our field (and my career).

Of equal or greater importance, Don was an exceptionally caring individual whose concern for others humanized the biomedical informatics field since its inception. We experienced this directly through the warm friendship you, Don, Linda, and I shared, which began with your visit to Pittsburgh in the 1980s. Under Don's guidance and 


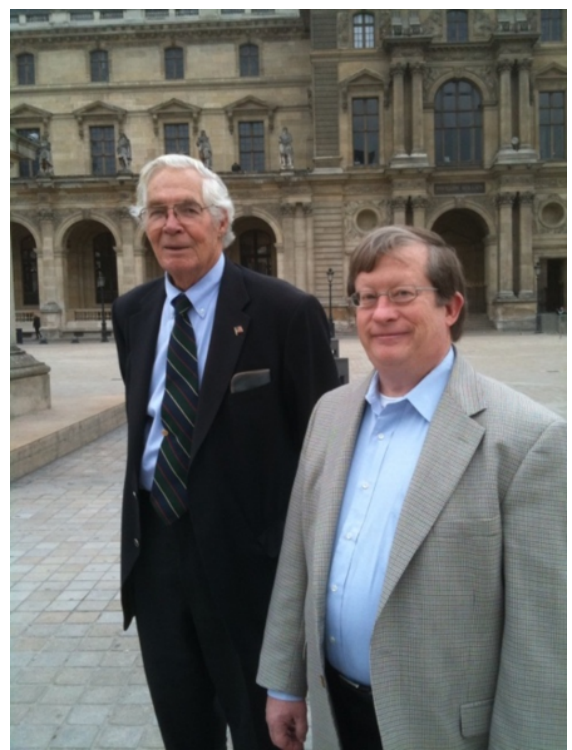

Dr. Lindberg (left) and Dr. Miller (right) in front of the Louvre in Paris in October 2009

with you often co-hosting, NLM's Biomedical Informatics, Library and Data Science/Biomedical Library and Informatics Review Committee's study sections met not just to review grant proposals but also to share group dinners and camaraderie at various sites in Bethesda and DC. The sense of shared friendship characterized the leadership style that Don encouraged in our field.

Don's love for his family also was evident in how, despite a busy and demanding job, he was always up to date on the activities of his children and grandchildren. I remember how you and Don hosted meals and swimming parties at your house for the initial groups of NLM trainees, which fostered lasting friendships among the participants. Don took a deep interest in professional activities and the lives and families of his acquaintances.

Don was a remarkable person who mastered every venue of a diverse set of interests. He also did so in a manner that inspired others. Don was exceedingly well-read and had a deep appreciation of history. He shared his opinions with an impressive mustering of facts and logic to support what he said. His photography skills brought delight and longlasting memories to many. Among other examples, Don enjoyed the opera and was a consummate expert in the intricacies of the composers, works, and performances.

Although the world has suffered a great loss in Don's passing, it is evident through his life and accomplishments he left us in a far better place. Our thoughts and prayers have been with you since we learned of Don's death.

\section{Reference}

Nerburn K. Neither wolf nor dog: on forgotten roads with an Indian elder. $25^{\text {th }}$ ed. Novato, CA.: New World Library; 2019. 